\title{
Permi loomastiil
}

Eero Autio

Joonis 1 kujutab pronksi valatud kolmepäist kotkast hella emanäo kujutisega selle rinnal. Motiiv juhatab meid otsekui lennult Uuralitest lääne pool elavate soome-ugri rahvaste hulka kuuluvate sürjakomide, permikomide ja udmurtide muinasaega ja nende tollase kunsti juurde, mille kohta kasutatakse kõige sagedamini terminit permi loomastiil. Selle õitseng kestis 6.-8/9. sajandini ja lõpp langes 14. sajandisse. Et obiugrilaste kunst on permi rahvaste omaga üsna sarnane ja pealegi elas Uuralitest lääne pool tol ajal manse (voguleid), tuleb ka neid permi kunsti käsitledes meeles pidada.

Permi pronksvalandid on 3-17 cm suurused. Neil kujutatakse veelinde, neljajalgseid ja röövlinde, kelle rinnal on nägu või isegi terve inimene (joonised 2-6). Niisama levinud on põdrapäine inimene (7) ja inimene, kelle käed on nagu linnu tiivad, pea läheb üle põdra peaks ning jalgade all on sisalikuks nimetatav loom (8). Selle temaatika kohta kasutatakse nimetust sulde. Kui inimese pea asemel on ainult põdra pea, kasutatakse nimetust inimpõder. Sageli on sulde-olendite vahele paigutatud inimene või nägu, mille kohal kaarduvad vastamisi asetatud põdrapead. Peale selle esineb jumalannadeks peetavaid (10) ja naise nägu kujutavaid motiive (11). Võrdluseks kõrvutatagu viimasega peaaegu samalaadset obi-ugri kujutist (12). Sarnasust võib märgata ka muude motiivide puhul (joonised 13 ja 14). Permi ja obi-ugri pronksvalandite hulgas moodustavad omaette rühma naiste eheteks klassifitseeritavad esemed,

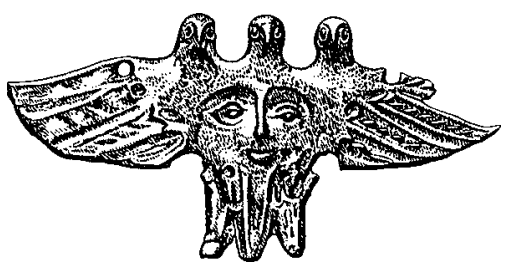

Joonis 1. Kolmepealine kotkas. 8.-9. sajand. Juhuslik leid. PermiKomi. Permi muuseumi Teplouhhovi kogu. (Gribova 1975: tahvel VI).

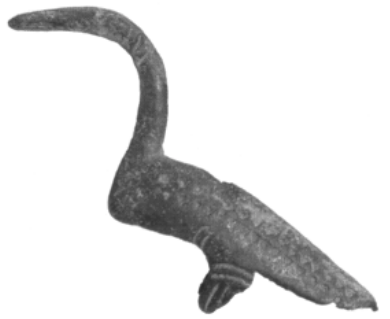

Joonis 2. Luik. 7.-8. saj. Skorodumi aardeleid, Permi kubermang. 5 × 9,2 cm. Permi muuseum. 


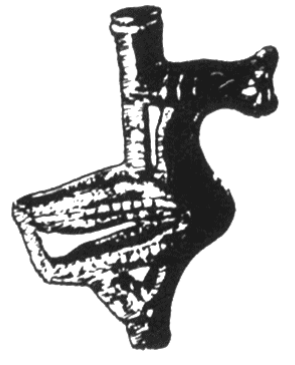

Joonis 3. Toruripats. 6.7. saj. Kama jõe ülemjooks, Permi kubermang. 8, $1 \times 6,4$ $\mathrm{cm}$. Permi ülikooli Zelikmani kogu.

Joonis 5. Lind inimesega rinnal, ripats. 10. -11. saj. Juhuleid, Permikomi. 4,3 x 6,7 cm. Permi muuseumi Teplouhhovi kogu.

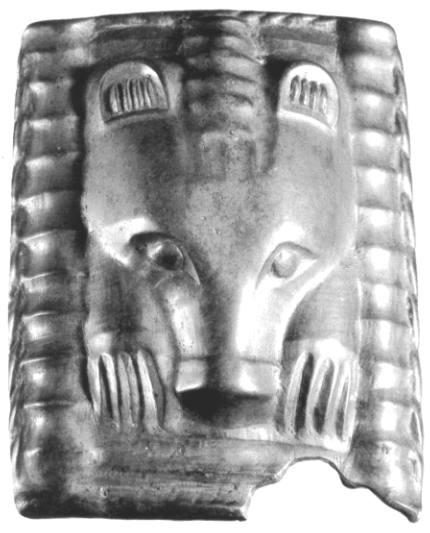

Joonis 6. Ohvriasendis karu, tagaosas riputusaasad. 4. või 5. saj (?). Leitud Kõni jõe äärest Permi kubermangust. $8 \times 6,5 \mathrm{~cm}$. Permi muuseumi Teplouhhovi kogu.

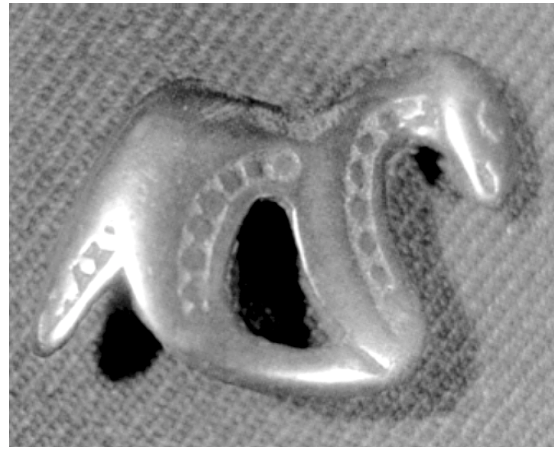

Joonis 4. Soobel (?). 7.-8. saj. Mihhailevo, Permikomi. 2,5 x 3,3 cm. Permi muuseum.

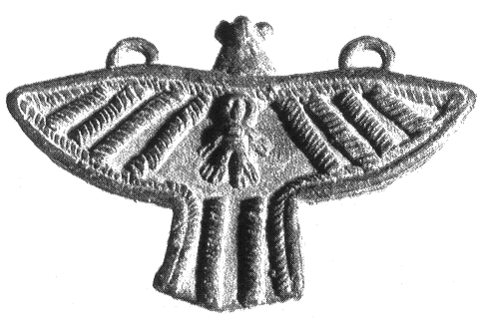

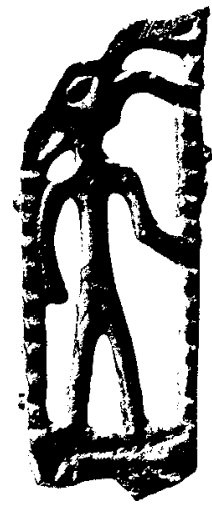

Joonis 7. Inimpõder. 7.-8. saj. Redikor, Permi kubermang. $6,3 \times 2,6 \mathrm{~cm}$. Tšerdõni muuseum (Oborin \& Tšagin 1988: pilt 89). 


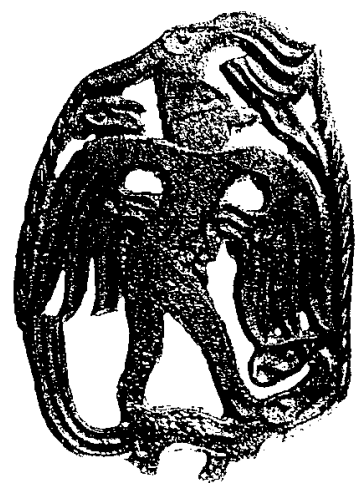

Joonis 8. Inimlindpõder (sulde). 7.-8. saj. Troitsko-Petšora ringkond, Komi. 9,2 × 6,7 cm. Riiklik ajaloomuuseum, Moskva (Oborin \& Tšagin 1988: 86).

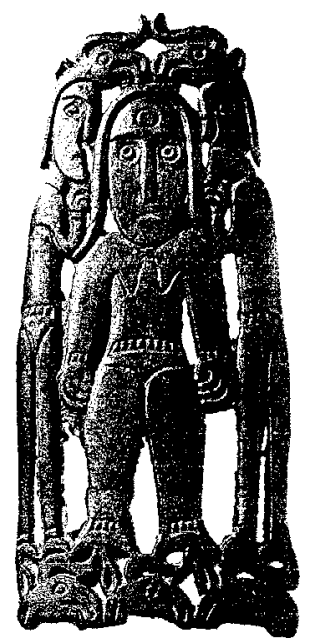

Joonis 10. Jumalanna, külgedel mehed, ülal ja all põdrapead. 6.-7. saj. Leitud aastal 1948 Kama jõkke suubuva Timšeri jõe suudmest. Tšerdõni rajoon, Permi kubermang. 14,5 x 6,3 cm. Tšerdõni muuseum.

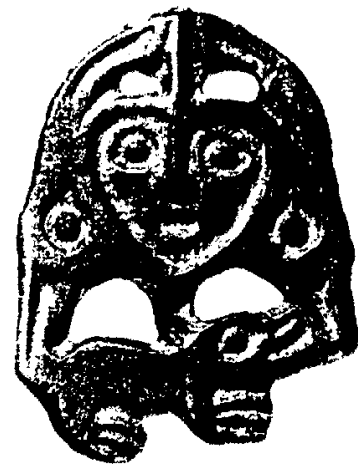

Joonis 9. Nägu, all sisalik ja külgedel põdrapead. 7.-8. saj. Leitud aastal 1985. Mogilniku küla, Permi kubermang. 3,6 6 2,7 cm. Tšerdõni muuseum (Oborin \& Tšagin 1988: 100).

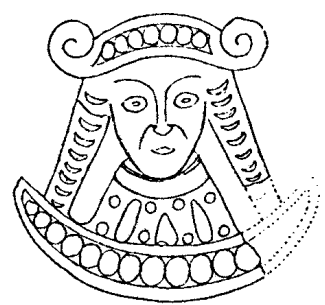

Joonis 11.-12. Naise näo motiiv: 11 - Permi lähedalt Gljadenovost, Spitsõn 64. 12 -obiugri variant, Tobolsk. Spitsõn 1906: 62.

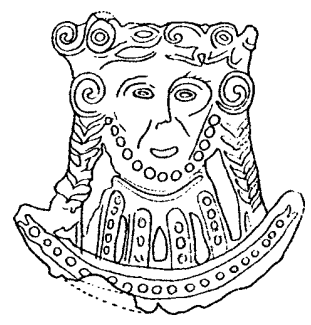




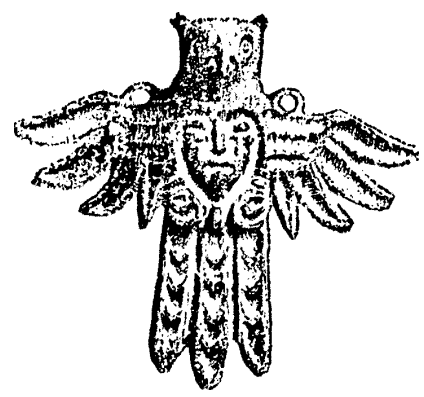

Joonis 13.-14. Lind näoga rinnal: 13-Permi, Nižne Moševo, Spitsõn 1906: 284. 14 - ohvriasendis karu, obi-ugri variant. Sotnikovskaja jurta. SKM (SU 5243: 64). Helsingi.

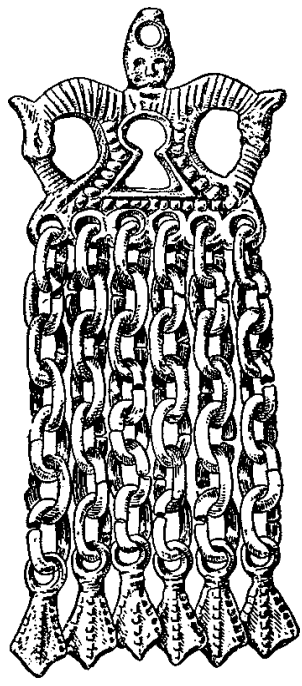

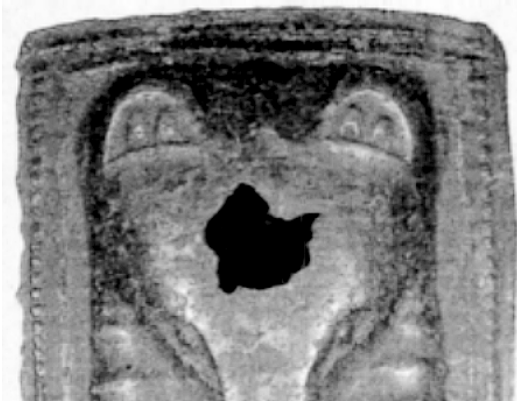
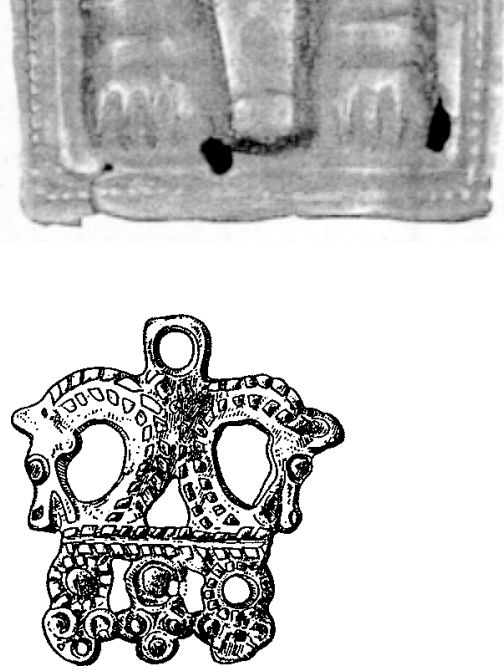

Joonis 15.-16. Hobusemotiiviga ripatseid: 15 Mihhailevo. 16-Urja. Mõlemad 6.-9. saj. (Smirnov 1952: XL-10 ja 8).

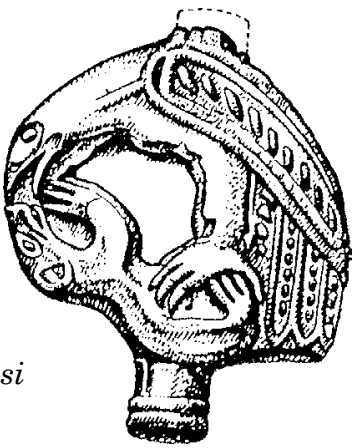

Joonis 17. Toruripats kahe koonud vastamisi looma motiiviga. (Gribova 1975: tahvel XII). 
nagu hobusemotiiviga ripatsid (joonised 15-16) ja kahte eri looma kujutavad nn toruripatsid (joonis 17).

Permi pronksvalandeid on leitud kalmistute, linnuste ja asulate väljakaevamistel, aardeleidudest, koobastest ja juhuslike leidudena. Kalmistud, ohvrikohad ja peidetud aarete asupaigad olid kohalikele elanikele pühad ning nende rüüstamine oleks võrdunud iseenda surmamõistmisega. Venelastest sissetungijad ei löönud kohkuma: karusnahkade kõrval ahvatleski neid ida suunas pürgima võimalus rüüstata pühapaiku. Sõdurid tegid musta töö ja vürstid said saagi. Nad kuhjasid kokku kollektsioone, millest tuntuim ja suurim kuulus Stroganovite suguseltsile, ütleb L. Gribova oma raamatus Permski zverinõi stil (vt lk 101-105).

Hiljem hankisid pronksvalandeid oma kogudesse ka mõned õpetlased, näiteks A. Teplouhhov ja M. Selikman. Eriti rohkesti leidub arheoloogiliste väljakaevamiste ja kogumistöö käigus saadud valandeid muidugi Permi muuseumi ja ülikooli kogudes. Peale selle on neid Tšerdõni ja Sõktõvkari muuseumides, Peterburis Ermitaažis ja Moskva Riikliku Ajaloomuusemi kogudes. Obiugri pronksvalandite osas on põhjust mainida Tomski ja Tobolski muuseumi. Permi loomastiili kuuluvate esemete koguhulk on teadmata. A. Spitsõni albumis (1906) on ligi 500 pronkseseme pildid, kuid pärast seda on neid leitud veel hulgaliselt.

\section{Pronksvalandid Soome ja Eesti muuseumides}

Permi pronksvalandeid on Soome jõudnud juba esiajaloolisel ajal: näiteks rinnal asetseva näoga kolmepealine kotkas (joonis 18) ja hobusemotiiviga ripatsid, mida on leitud neli (joonis 19). Peale selle on neid kaasa toonud Soome teadlased: J. R. Aspelin tõi aastail 1858 ja 1873 Permist hobusemotiiviga ripatseid (SKM 1399: 100 ja 111), kõrvulise toruripatsi (1399: 101) ja viis fantastilist linnukujutist (näiteina joonised 21-23). Axel Heikel ostis aastal 1885 Kaasanist hobusemotiiviga ripatsi (SKM 2940: 71) ja sai "metsahärralt” F. A. Teplouhhovilt veelinnumotiiviga valandi (joonis 24), ripatsehteid (2940: 67 ja 68) ja veelinnumotiiviga toruripatsi (2940: 71). Artturi Kannisto tõi oma Siberi-matkalt aastal 1907 hobust kujutava "ripatsi" (joonis 25) ning K. F. Karjalainen (1898-1902) Siberist kotkamotiiviga valandi (SKM SU 5243: 63) ja medaljoni, millel on kujutatud ohvriasendis karu (joonis 14). M. Znamenski 

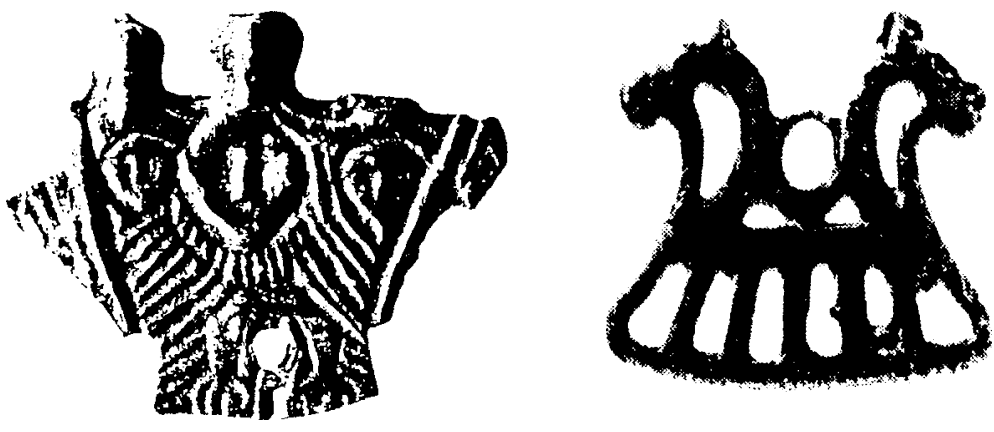

Joonis 18.-20. Esiajaloolisel ajal Soome jõudnud pronksvalandeid. 18 - Juupajoki, Lääne-Soome. Leitud aastal 1911. SKM (7881). Helsingi. 19 - Juntusranta Suomussalmi, Huurre 1983, 359. 20 - Vilusenharju, Tampere. 4,3 $x$ 5,2 cm. SKM (18556: 820). Helsingi.
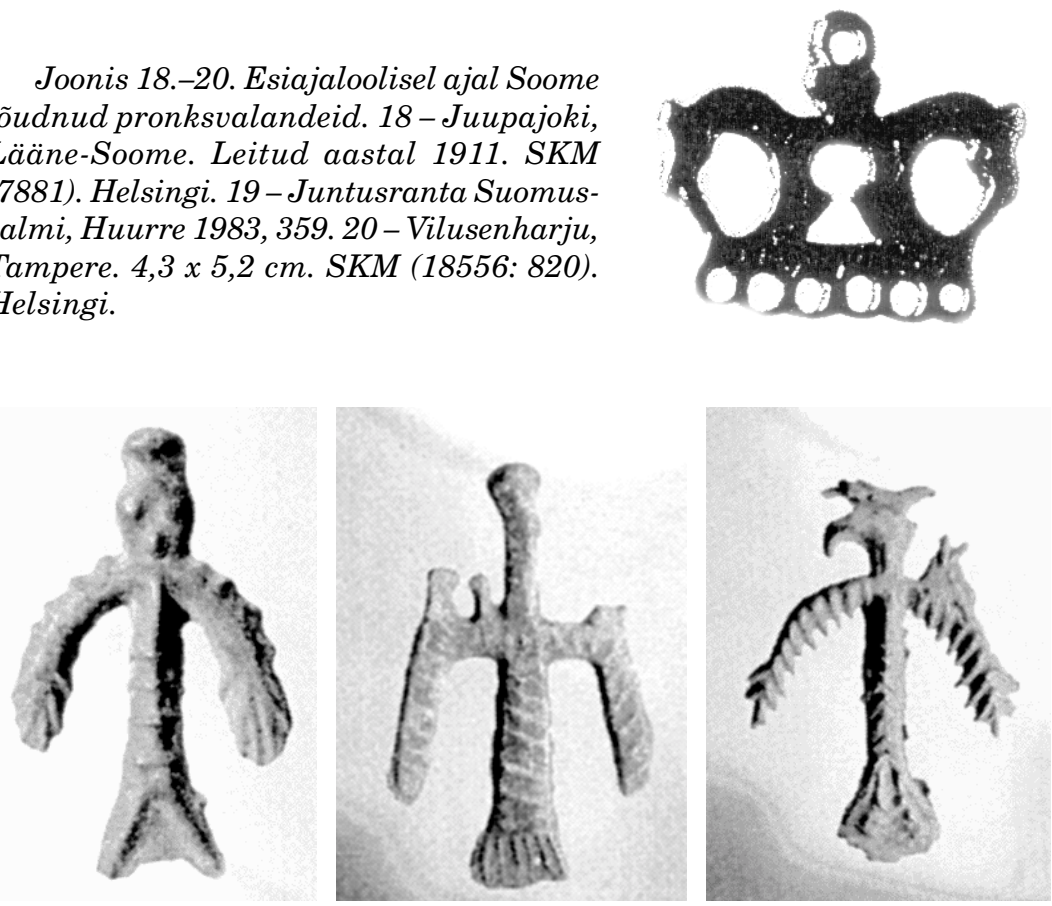

Joonis 21.-23. J. Aspelin tõi aastal 1873 "Permast" viis "fantastilist" linnupilti, millest siinkohal on ära toodud kolm. Vanus: 4.-1. saj eKr (vrd Smirnov 1952: 255), kõrgused 7-8 cm. SMK (1399: 102). Helsingi. 


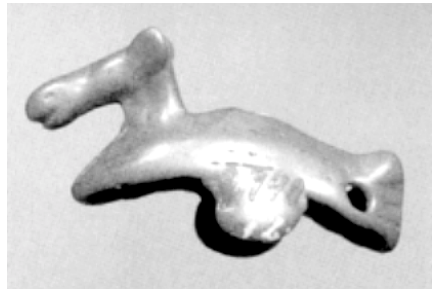

Joonis 24. Axel Heikeli aastal 1893 Permist toodud veelind, kellel on põdra pea. 6.-8. saj. (Vrd Oborin \& Tšagin 1988: joonis 63). Kotša, Tšerdõni rajoon. $2,5 \times 4,8 \mathrm{~cm}$. SKM (2940: 72). Helsingi.

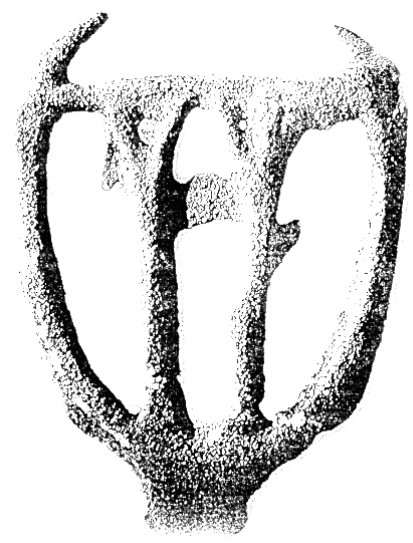

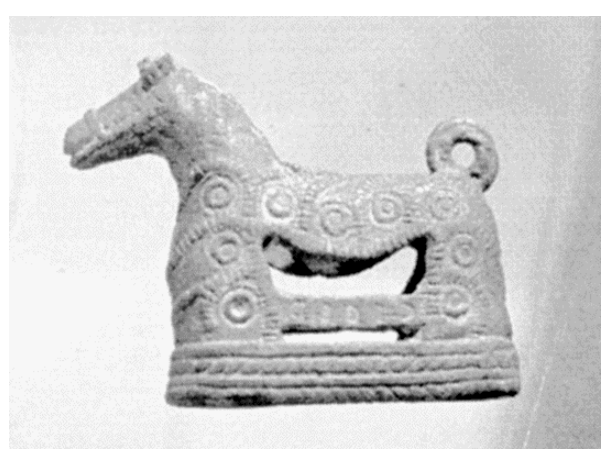

Joonis 25. Artturi Kannisto aastal 1907 Siberist toodud hobusemotiiviga õones "ripats" (peaks olema tuleraua käepide (vrd "Komi jözkostsa iskusstvo", joonis 12), mis võiks pärineda 11.-12. sajandist). Leitud Verh Belõmi vallast. 5,9 $x$ 7,5 cm. SKM (4870:23). Helsingi.

Joonis 26. K. R. Donneri aastal 1914 Siberist toodud kogusse kuuluv valand. N. Kossarev (1984) seostab sedalaadi motiive elupuud puudutavate uskumustega ja dateerib need varasesse rauaaega (lk 202-203). Kogusse kuuluvad esemed on leitud Tomski kubermangust Ragovitsa lähistelt. Suurus umbes $6,5 \mathrm{~cm}$. SKM (6607:1). Helsingi.

kinkis Soome ekspeditsioonirahvale 1887. a Tobolskis pardimotiiviga ripatsi (SKM 2599: 2). Kui lisada neile K. R. Donneri kogu (SKM 6607: 1-21), mille esemete hulgast on siinkohal motiivinäitena ära toodud üks (joonis 26), võib öelda, et Soomes on üsna palju Permi pronksvalandeid.

Arheoloog Heikki Pauts ütles, et esiajaloolisel ajal ei ole Permi pronksvalandeid Eestisse sattunud. Eestis neid siiski on, kuna Paul von Krusenstern kinkis 1873. a Tallinna ajaloomuuseumile 16 Petšora jõe keskjooksult pärinevat valandit. Neist on siinkohal 
näiteina ära toodud pikasabaline lind (joonis 27), eelajaloolistel kaljujoonistel leiduvaga sarnane vene (28), inimpõder (29) ja nägusid kujutavad valandid (30-32). Peale Krusensterni kogu on muuseumis vürstitar Katherina de la Gardie poolt aastal 1891 kingitud valand (AM 197), mis teatakse pärinevat Nižni Novgorodi piirkonnast.

\section{Ülevaade uurimisloost}

Permi pronksvalandeid on esmakordselt mainitud hollandlase Nikolaus Witseni reisikirjeldustes 17. sajandi lõpul. Vene rändurid hakkasid neist kirjutama 19. sajandi keskpaigas. Lääne uurijateni jõudis vastavasisuline teave alates 1877. aastast, kuna siis hakkas soome arheoloog J. R. Aspelin, kes oli teinud väljakaevamisi Venemaal, avaldama pronksvalandite pilte vihkudena ilmuvais albumeis Antiquités Nord Finno-Ougrien (1877-1884). Aspelin oletas juba tollal, et mitmed motiivid kujutavad uskumusolendeid ja jumalusi.

Venemaal tärkas huvi Permi pronksvalandite vastu 19. sajandi lõpul. Aastal 1893 kirjutas F. Teplouhhov artikli Permi tšuudidest ehk soome-ugri rahvastest ja nende fantastilistest pronkspiltidest. 1899. a ilmus arheoloog D. Anutšini ulatuslik artikkel tšuudide uskumustest ja kunstist, kus oletati, et kotkamotiiv on jõudnud permi rahvasteni sküütide ja sarmaatide vahendusel Indiast. Ka arheoloog A. Spitsõn kirjutas Permi pronksvalandeist, seostades neid šamanismiga. 1906. aastal avaldas ta oma mahuka albumi Šamanskije izobraženija, mis pildimaterjali tõttu on praegugi kasutuskõlblik. Spitsõn dateeris permi kunsti õitseajaks 7.-8. sajandi ning otsis selle motiivistikus mõjutusi Iraanist ja Lähis-Idast.

Aastal 1887 mindi Soomest uurimisreisile Ida-Venemaale ja Siberisse. Kaasas oli ka O. Hj. Appelgren-Kivalo, kes avaldas 1912. aastal artikli sküüdi-permi tarbekunstist ning tõestas, et rinnale loodud näo ning lahtiste tiibadega linnumotiivil on olemas eeskuju kreeka Ganymedese-müüti kujutatavates joonistustes, kusjuures Permi piirkonnas on inimese kujutisest jäänud järele vaid nägu. 20. sajandi algupoole silmapaistvaim soome arheoloog, kes oli huvitatud permi kunstist, oli A. M. Tallgren (1885-1945). Ta oli teinud väljakaevamisi Venemaal ka pärast revolutsiooni, jälgis seal- 

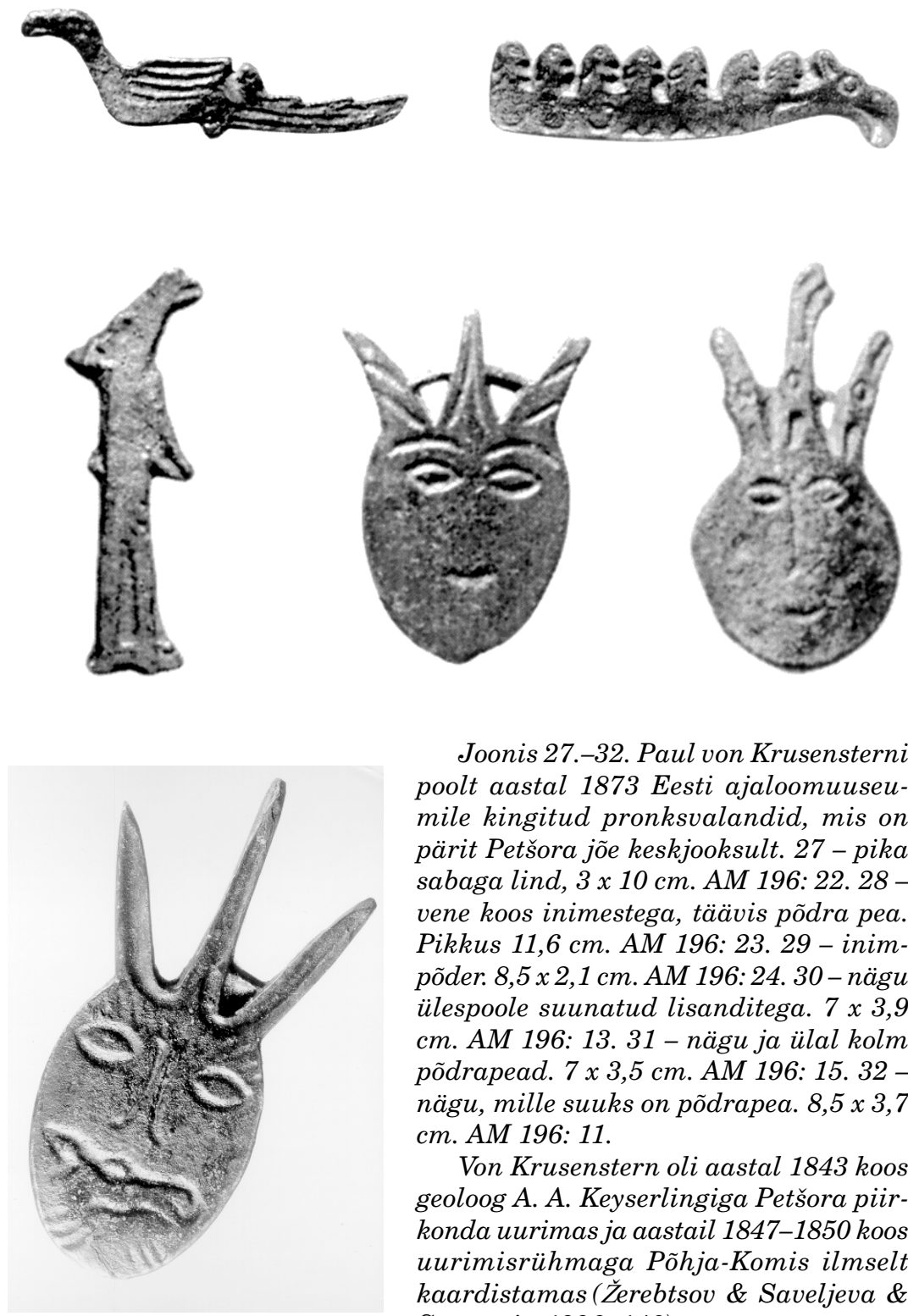

Joonis 27.-32. Paul von Krusensterni poolt aastal 1873 Eesti ajaloomuuseumile kingitud pronksvalandid, mis on pärit Petšora jõe keskjooksult. 27 - pika sabaga lind, $3 \times 10 \mathrm{~cm}$. AM 196: 22.28 vene koos inimestega, täävis põdra pea. Pikkus 11,6 cm. AM 196: 23. 29 - inimpõder. 8,5 x 2,1 cm. AM 196: 24. 30-nägu ülespoole suunatud lisanditega. 7 × 3,9 cm. AM 196: 13. 31 - nägu ja ülal kolm põdrapead. $7 \times 3,5 \mathrm{~cm}$. AM 196: 15. 32 nägu, mille suuks on põdrapea. 8,5 53,7 cm. AM 196: 11.

Von Krusenstern oli aastal 1843 koos geoloog A. A. Keyserlingiga Petšora piirkonda uurimas ja aastail 1847-1850 koos uurimisrühmaga Põhja-Komis ilmselt kaardistamas (Žerebtsov \& Saveljeva \& Smetanin 1996: 146). 
se arheoloogia arengut ja kirjutas sellest teaduslikele väljaannetele ülevaateid saksa, prantsuse, inglise, rootsi ja soome keeles. Tallgren oli aastail 1920-1923 Tartu ülikooli arheoloogia professor. Permi kunsti käsitlustest mainitagu tema artiklit Die Altpermische Pelzwarenperiode an der Petšora (1934). Tallgreni seisukoht oli, et permi kunst sai obiugrilaste vahendusel mõjutusi Kesk-Aasiast (Tallgren 1931, 123-124).

Pärast Venemaa revolutsiooni algas permi kunsti uurimises uus etapp. Tähelepanu pöörati materiaalse kultuuri erinevaile tasandeile ja nende mõjule uskumuste ja kunsti vallas. Uusi metoodilisi juhtnööre järgides selgitas arheoloog A. Šmidt (1927) rinnale loodud näoga linnumotiivi esinemist erinevail kultuuriperioodidel. Ta märkas, et varaseimal ajajärgul kujutati vaid silmi ja suud, järgmisel nägu ja alles kolmandal etapil kogu inimest. Ta välistas Ganymedese-müüdil põhinevad seletused ja arvas, et tegu on sküüdi motiiviga.

1950. aastate alguses hakkas Nõukogude Liidus kinnistuma seisukoht, mille kohaselt enamik motiive on permi algupära. Nii tõdes näiteks A. Zbrujeva (1959), et sküütide puhul väga levinud tiivulise lõvi ja lendava põhjapõdra kujutised permi kunstis ei esine, nende asemel on aga tuntud karu, hunt, põder ja teised kodused motiivid. Ananjino kultuuri (1500-900/800 eKr) uurijana viis ta paljude motiivide juured tagasi nimetatud aega ja tõlgendas neid uskumustega, mis on seotud päikese, totemismi, jumal-ema ja müütidega.

Veelgi kaugemale läks kunsti juuri otsides arheoloog A. Smirnov (1952), kes dateeris selle sünni Gorbunovo soost leitud esemete põhjal aega 2-3 tuhat aastat enne Kristust. Ta väitis, et mõjutusi on saadud antiigist, sküütidelt ja sarmaatidelt, idast ja lõunast, kuid need pole ulatunud motiivide sisuni. Smirnov rõhutas valandite seost šamaanikultuse ja totemismiga. Oma tõlgendustes tugines ta uskumustele ja arvas näiteks naisratsanikumotiivi seostuvat traditsiooniliste pidustustega, kus kevadet sümboliseeris lilledega ehitud neiu valgel hobusel. Smirnovi peetakse eriti silmapaistvaks uurijaks, ütleb Kronid Korepanov oma uurimisajalugu käsitlevas artiklis (1978), mida olen paljuski järginud. Hobusemotiiviga seoses tuleb mainida arheoloog L. Golubevat, kuna tema eriala on naiste seas armastatud hobusemotiiviga ripatsid (1966) ja üldse naisteehted, olgu nende motiivideks siis päike (1978) või loomad (1979). 


\section{Impulss Koola poolsaarelt - totemism?}

Tänu väljakaevamistele ja nende põhjal avaldatud uurimustele olid arheoloogiline aines ja teadmised 1960. aastate alguseks tublisti suurenenud. Permi kunsti tõlgendamise seisukohalt tuli viljakas impulss siiski Koola poolsaarelt. Sealseid rahvajutte kogunud V. Tšarnoluski avaldas aastal 1965 raamatu Legenda ob olene-tšeloveke, mis sisaldab tootempõhjapõder Meandašist ${ }^{1}$ jutustavaid muistendeid. Ulukpõhjapõdra ja inimesena esinev Meandaš võttis naiseks lapi tüdruku ja neil sündisid lapsed. Muistendid, nendega seotud uskumused ja kombestik on ilmselgelt totemistlikud. Ermitaažis töötades tegeles Tšarnoluski Permi pronksvalanditega, mille motiiviks on inimpõder, ning pidas neid julgelt saami juttude pildilisteks vasteteks.

Tšarnoluski teos äratas tähelepanu. Aastal 1972 ilmus ühes komi etnograafiaalases väljaandes L. Gribova artikkel Permi pronksvalandite tõlgendamisest. Kuigi Gribova polnud kõigi Tšarnoluski kõrvutustega nõus, kasutas ta inimpõdra kohta nimetust Meandaš. See kinnistus erialakirjanduses ja näib olevat kasutusel ka uusimais kirjutisis. Teema ulatuslikkuse tõttu avaldas Gribova oma totemismist lähtuvad tõlgendused koos põhjendustega raamatus Permski zverinõi stil (1975). Gribova oli soome-ugri tarbekunsti põhjalikult sisse elanud, oskas komi keelt ja oli juba lapsepõlves kuulnud komi muistendeid ja uskumusi. Usutavaim tema seletustest puudutab motiivi, kus on kaks looma, koonud vastamisi (joonis 17). Gribova ei nõustu tõlgendustega, mille kohaselt motiiv kujutab hõimude omavahelist võitlust. Kõne all olev asend naiste toruripatseil, mida kanti rinnal või puusa(de)l, osutab naiste silmis olulistele või lähedastele asjadele ehk armastusele ja abielule. Gribova püüd seletada erinevate motiivide teket uute hõimude sünniga ei ole usutav. Seevastu kõlbab tema analüüs motiivide eri osade kokkukuulumisest uurijaile paljuski eeskujuks.

Ka komi rahvapärimuste uurija A. Sidorov avaldas 1972. aastal pronksvalandeid käsitleva artikli samas väljaandes, kus Gribova. Sidorovi arvates seletuvad üksikud loomakujutised totemismiga. Mitme kujutisega valandite keskne motiiv sümboliseerib maailma loojat ja inimkonna esiema. Kolm kotka- või põdrapead viitavad lisaks tootemrühmale ka päikesele. Päikesele ja taevale osutavad ka sulde-olendite tiivad, mis on jäänuk varasemast ajajärgust, nagu 
ka linnu nokka meenutav nina ja kolmesõrmelisus. Sagedast linnumotiivi kasutamist põhjendades viitab Sidorov permikomi loomismüüdile. Selle järgi munes esiema Tšõž ehk metspart kuus muna, millest sai alguse maailm. Valandite allserva paigutatud sisalik on Sidorovi järgi päikesele vaenulik vastandjõud. Oma tõlgendust toetamaks jutustab ta sisalikuga seotud uskumuse, kuid sellest hoolimata ei ole seletus usutav, kuna valandite sisalik on kujutatud ka ratsuna.

\section{Kriitikat ja šamanismi}

Akadeemik V. Rõbakov arvustab oma artiklis (1979) Tšarnoluskit, kuna see pole piisavalt tundnud permi rahvaste mütoloogiat, ja Gribovat, sest too oli liialt innustunud totemismist. Innustunud näib olevat ka Rõbakov, kui ta väidab, et Äänisjärve Oleni saare kalmistu šamaani instrumendiks nimetatud põdrapealine sau (joonis 33) kõlbab "täpselt" (lk 18) 34. joonisel sulde-olendite vahel seisva šamaani kohale paigutatud sümboliks. Sarnasuse põhjal arvab Rõbakov, et joonisel 35 on tiivuline šamaan ja joonisel 36 on linnu ülesanne šamaan taevasse aidata.

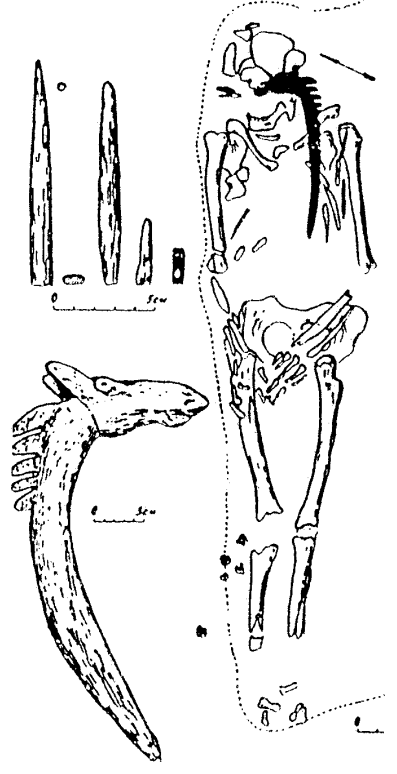

Rõbakov sai tuge L. Tšižovalt, kes laitis Gribovat ja Sidorovi selle eest, et nood ei olnud kasutanud arheoloogilist ainest. Tšižova (1982) heidabki pilgu arheoloogilistele kultuuridele ja šamanismi arengule. Tema söandab Permi valanditel isegi ära tunda valgeid ja musti šamaane. Valge šamaan kasutas taevast sümboliseerivat põdrapeamaski, must šamaan aga loomapeakatet, külastades ka allilma.

Rõbakovi tõlgendusist väärib tähelepanu tema väide, et põtrade vastamisi asetatud koonud moodustavad otsekui taevavõlvi. Mulje on tõesti harras ja inim-

Joonis 33. Kultusesau Oleni saare kalmistu hauast nr 152 (Gurina 1956). 

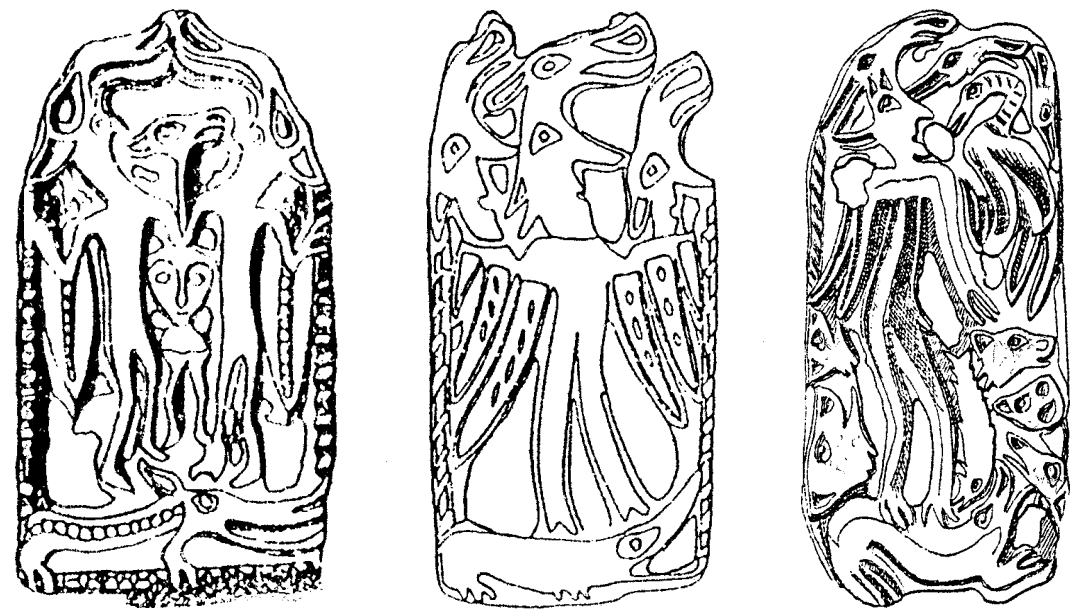

Joonised 34.-36. Rõbakovi tõlgendusi: 34 - šamaan, 35 - tiibadega šamaan, 36 - lind abivaimuna. (Spitsõn1906: 170 Peškova, 117 Uhta, 127 Uhta).

kujud koonude all on turvalises paigas. Uus ja märkimisväärne on sisaliku pidamine öö ja päeva vaheldumise sümboliks. Tšižova seletustest on usutavaimad need, mis puudutavad abielupaari ja peret.

Siberi šamanismi juurde on kuulunud loomarekvisiitide kasutamine, kuid permi rahvaste, nagu teistegi soomeugrilaste šamaanid ei ole kasutanud sarvi ega loomapeakatteid. Neist ei leidu märke ei lapi nõiatrummidel ega ka obiugrilaste kunstis (Autio 1995). Äänisjärve Oleni saare põdrapäine sau ei sobi šamaani atribuudiks, sest Karjalas Võgi jõe kaljujoonistel on kujutatud rituaalset rongkäiku, kus paljud osavõtjad kannavad käes looma- ja inimpealisi kultusesemeid. Põdrapäine sau on tõenäolisemalt totemismile osutav sümbol, nagu arvab ka Studzitskaja (1994).

\section{Hingede peatuspaigad või hoidlad?}

Paljud uurijad oletavad, et pronksvalandid on tehtud kadunukeste hingede hoidmiseks. Sellise seletuseni jõudis 1984. aastal ka Gribova oma Heibida-Pedarõ pronksvalandeid käsitlevas artiklis, kuid sellest hoolimata ei loobunud ta ka totemismi tähtsustamisest. Tšižovagi polnud oma varasemate tõlgendustega päris rahul ning naa- 
sis Permi pronksvalandite motiivide juurde 1987. a artiklis. Uurinud Siberi põlisrahvaste uskumusi, mis on seotud hingega, järeldab ta, et vaid karu kujutavaid valandeid on võimalik seletada totemismiga. Niisugused ühendmotiivid, kus kujutatakse inimest ja mõnd looma või lindu ehk ka ainult inimest või tema pead, oleksid siis valmistatud peatuspaigaks hingedele.

Hingede eest hoolitsemine võiks olla piisavalt tähtis põhjus, et valada nende asupaigaks pronkskujutisi. Mõned obi-ugri valandid, eriti need, kus on kujutatud suletud silmadega inimest, võiksid seega olla hingede hoiukohad. Valandite suurus $(4-6 \mathrm{~cm})$, medaljonitaoline kuju ja riputamise tarvis tehtud aas või auk annavad siiski põhjust oletada, et tegu on pigem mälestusesemete kui hingede asupaikadega. Mis puutub inimese ja looma või linnu ühendamisse, siis seda on kindlam seletada totemismi kui hingede hoidmisega.

\section{Elupuu kasutamine tõlgendustes}

Viimastel aastakümnetel on soositud elupuuga seotud uskumustest lähtuvad tõlgendused. Obiugrilaste minevikku uurinud arheoloog M. Kossarev (1984: 202) tõdeb, et vastavaid uskumusi esines vaseja pronksiajal ning eriti rauaajal. Tema avaldatud pronksvalandite seas on vaieldamatult neid, mille motiiviks on loomapeadega lõppevate okste ja ladvaga puu (näiteks joonis 37). Elupuud puudutavail uskumustel on niisiis alust, kuid neist ei piisa kõigi motiivide nii valdavaks seletamiseks, nagu I. Iljina (1994) ja K. Korepanov (1995) seda on teinud. Kõige kindlamalt võib elupuust lähtuvat seletust rakendada joonisel 38 näha oleva motiivi puhul, kus inimese peast ja kätest kasvavad välja loomapead, moodustades otsekui puu. Kas sellega on ka tahetud kujutada loomade paljunemist, jäägu vaataja juurelda. Korepanovi arvates kujutab sisalik maad, kust puu saab oma jõu, ja Iljina arvates allilma või põrgut.

\section{Uusi tõlgendusi ja meetodeid}

Udmurdi arheoloog Nadežda Šutova pidas 1995. aastal Jyväskyläs fennougristide kongressil ettekande, mille teemaks oli muinasudmurdi jumalatar ja selle rekonstrueerimise võimal(ikk)us. Ta alustas rekonstrueerimist, jälgides ripatseid, mille motiivideks on 


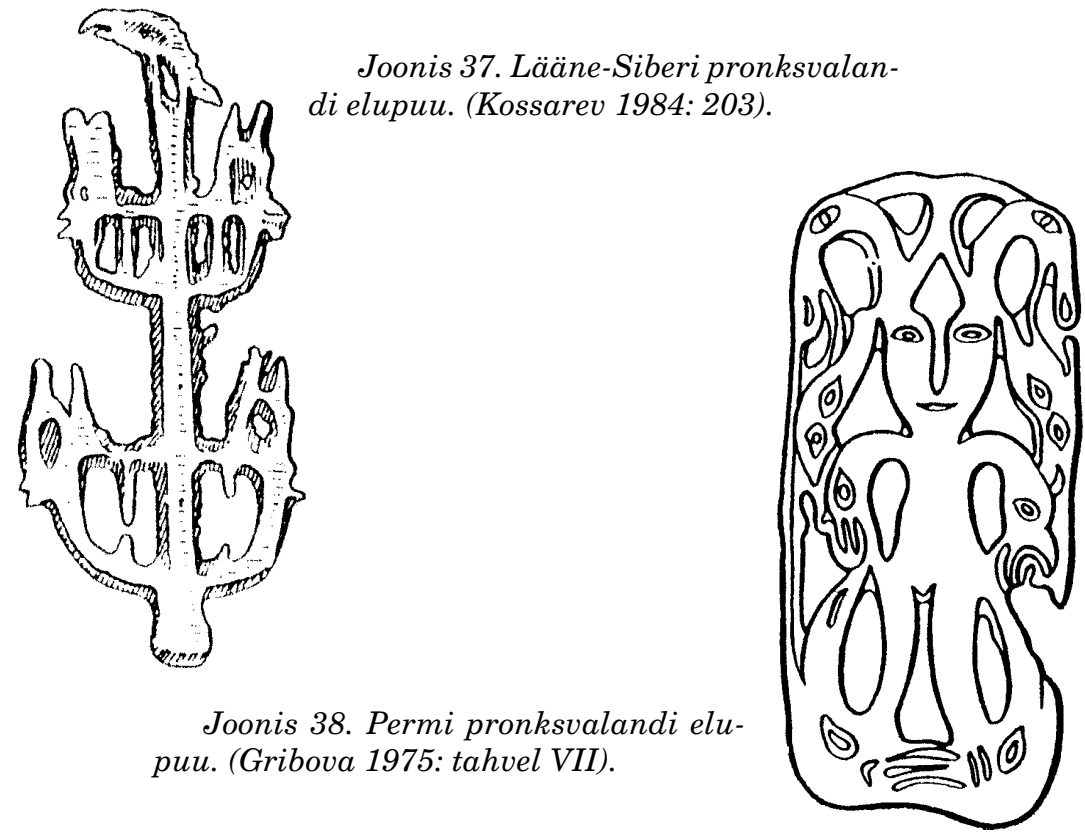

eri suundadesse vaatavad hobuste pead inimpeaga nende vahel ning allservas kettide otsas rippuvad metspardi jalad (joonis 15). Tema arvates sümboliseerisid hobuste pead päikesehobust ning öö ja päeva vaheldumist, inimpea aga jumalatari, kes oli ühenduses nii siin- kui ka sealpoolse ilmaga.

Motiiv, mis koosneb naisratsanikust ja valandi alaserva paigutatud maost (joonis 39), ei kujuta Šutova meelest päikese ja manala vahelist võitlust, nagu Smirnov oli seda tõlgendanud. Hobuse ja mao suhe on tasakaalukas ja rahulik, väidab Štova. Naisratsanik on kõige oleva ema ja hobune liiklusvahend pääsemaks üla- ja allilma.

Udmurdi pärimusteadete kohaselt olid kõrgeimad jumalad Inmar, Kvasja ja Kõldõsin meessoost. Viimati mainitu oli maa ja saagi jumal ning sellele lisaks

Joonis 39. Naisratsanik. Glazovi piirkond. 8.-9. saj. (Golubeva 1979: tahvel 16-2).

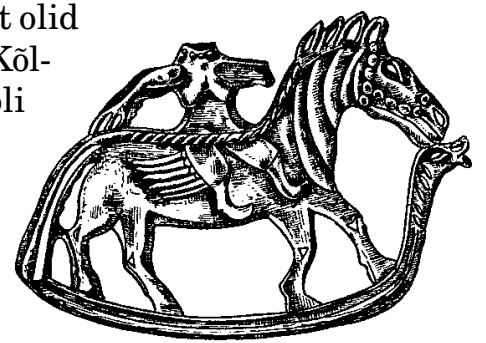


naiste ja laste kaitsja. Sõna kõldõs tähendab permi keeltes 'loovat, viljastavat' ja -in 'naist, emast (looma), ema ja ämma'. Kõldõsin elas algul maa peal, kuid solvus inimeste käitumise peale ja läks taevasse või teiste teadete kohaselt maa alla. Taevasse tõusnu segunes Inmariga ja maa alla läinust sai Mu-Kõldõsin, kes oli viljakuse jumal, andis lastele hinge, kaitses noori emasid ja suguseltsi heaolu. Komidel oli vastav jumal Zarni-an ehk Kuldnaine, maridel ŠunŠotšõnava ehk kõige oleva ema ja mansidel Kaltaš-ekva, kes oli kõrgeima jumala naine ja õde.

Need teated viib Šutova kokku joonistel 10, 40 ja 41 näha olevate pronksvalandite ning teiste nendesarnastega, mis kujutavad ilmselgelt jumalatari. Tema arvates kehastab laia tuntuse ja poolehoiu võitnud jumalatar tervet ja tugevat naist, kes oli kõige loodu algus, andis elu taimedele, loomadele ja inimestele ning määras nende saatuse. Selles personifitseerus sünd, kasvamine, surm ja taassünd. Jumalatar muutus meessoost jumalaks teise aastatuhande algul, kuid säilitas oma eelkäija funktsioone. Muutumisprotsessist jutustab Šutova oma 1998. a ilmunud artiklis. Sealsete väidete kohaselt sümboliseerib Kõldõsini maa peal elatud elu õnnelikku aega ning solvumine 16. sajandil aset leidnud sõdu ja kannatusi.

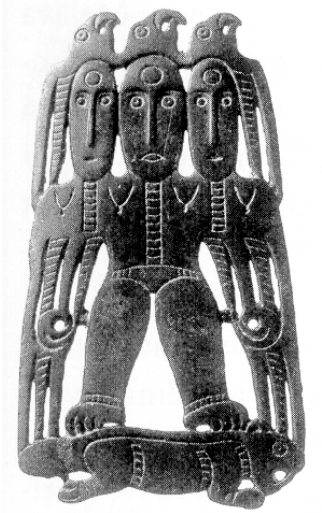

Joonis 40. Jumalanna. 7.-8. saj. Leitud aastal 1911 kolme vana kuuse juurte alt. Ust-Kaibi küla, Tšerdõni rajoon. 16,4x $9 \mathrm{~cm}$. Tšerdõni muuseum.

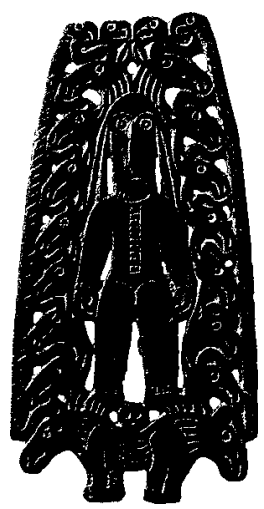

Joonis 41. Jumalanna. 7.-8. saj. Leitud tammi ehitades Timšeri jõe suudmest aastal 1946. Tšerdõni rajoon. 16,2 $\times 8 \mathrm{~cm}$. Tร̌erdõni muuseum.

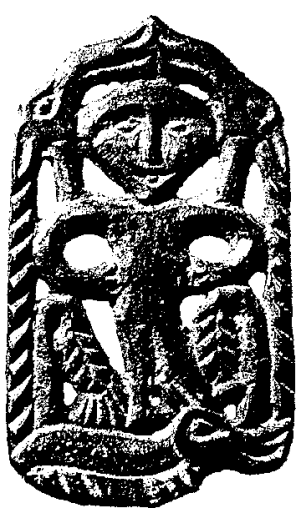

Joonis 42. "Odrajumal”. 8.-9. saj. Omelino (Lukojanov), Tšerdõni rajoon. Leitud 1904. a, kuid Tšerdõni muuseumile antud alles 1950. a. 5,5 $53 \mathrm{~cm}$. 
Šutova rekonstruktsioon on teretulnud lisa pronksvalandite tõlgendustele. Tekib tahtmine sobitada seda ka motiiviga, kus on inimene koos viljapeadega käsivarte all (joonis 42). Uno Holmberg kirjeldab oma raamatus Permalaisten uskonto udmurdi palvet, mis lõpeb lootusega, et Mu-Kõldõsin laseks kõrrel painduda terade raskuse all (Holmberg 1914: 200). Olgu öeldud, et kõnealune valand on leitud tšuudide põllult ja et kohalikud elanikud pidasid seda odrajumalaks.

Uutest meetoditest väärib kõige enam tähelepanu arheoloog Natalja Tšesnokova uurimus (1988), mille aineks on Komi alalt leitud 166 müüdiainelist valandit. Ta määrab neile proportsioonide alusel täpsed matemaatilised indeksid ja liigitab erinevad tüübid pea- ja alarühmadeks. Nii saab ka teadmata leiukohtadest pärit valandid paigutada õigetesse seostesse nii vanuse kui koha osas. Ootuspäraselt esinevad üksikud loomamotiivid (tüüp 6) kogu kõnealusel alal. Kuigi 1. tüüpi (sulde) võib leida Petšorast lääne pool ja 4. tüüpi (lind näoga rinnal) Petšora ülemjooksul, Višera jõe ääres ja Võtšegda lisajõgede ääres, on neil kõige rohkem sarnaseid jooni. Minu arvates toetab see totemistlikke tõlgendusi.

Tšesnokovat ei huvitanud mitte totemism, vaid komi rahva muistsed müüdid. Artiklis The Myth of the Northern Sub-Urals (1995) tõdeb ta, et ristiusu varaste mõjutuste tõttu on müüdid ununenud, kuid neist on siiski säilinud fragmente muistendites, eepilistes ja muudes lauludes ning ikonograafias ehk kujutiste motiivides. Ta alustab vaatlust veelinnu-motiividest ja osutab oma joonistega, et mõne motiivi puhul on pardi jalg otsekui põdra pea, mõnel puhul on aga pardil põdra pea. On ka valandeid, millel on kujutatud kahte parti. Nende seletuseks jutustab ta permikomi müüdi, mille kohaselt ürgmeres ujuv part munes kuus muna. Kahest haudus ta pojad, kellest sai kaks vastandlikku jumalat - Jen ja Omöl, hea ja kuri. Sõna tšož tähendab Tšesnokova järgi lelle ja onu, sugulast ja esiisa. Loomisloo part ei ole siiski tšož, vaid $t$ šǒž, postpositsioonina tähendab see 'ajal, jooksul', näiteks vežon ť̌̃ǒz = 'nädala jooksul', verb ť̃̃õnny = 'säästa, koguda', ja liitsõna tšõžiõv = 'ternespiim' ehk esimene piim pärast poegimist.

Sõnade tšož ja tšõž tähenduserinevused sunnivad kahtlema võimaluses seletada pardile ja põdrale osutavaid jooni tššz -sõna abil. Tähelepanu väärib Tšesnokova järeldus, mille kohaselt kõigis müüdiainelistes valandites esineb ... the complicated mythological image of the Premordial Bird chozh (Chesnokova 1995: 51). Tegelikult 
Joonis 43. Toruripats kahe veelinnu motiiviga. Garamihha. (Spitsõn 1906: 328).

laiendavad sõna tšõž tähendusvarjundid kogu motiivi tähendust. Mina ise pean parti kõige oleva alguseks ning selle ajaga seotud tähendus näib osutavat, et alles aeg on andnud kõigele olevale tajutava kuju (Autio 2000: 84). Tšesnokova teene on, et ta pöörab tähelepanu väiksemailegi üksikasjule ja käsitleb pronksesemeid graafiliselt. Tema tõlgendustest on usutavaim tšõž-muis-

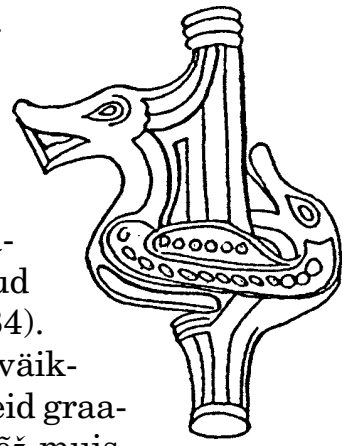
tendi sobitamine kahe pardi motiiviga (joonis 43 ).

\section{Soome-ugri rahvaste kujutiste traditsioon}

Esiajaloolise kunsti tundja arheoloog A. Formozov (1969: 228) nendib, et nimelt soome-ugri rahvastel on kiviajast alguse saanud ikonograafiline traditsioon, mis jätkub Põhja-Vene metallvalandite motiivides. V. Oborin ja G. Tšagin oletavad oma raamatus Iskusstvo Prikamja (1988: 16), et selle kunsti juured ulatuvad koos Kapova koopamaalingutega aega umbes 30000 aastat eKr. Isegi kui kõnealuste maalingute vanus oleks vaid 15000 aastat, nagu arvavad M. Obõdenov ja K. Korepanov (1997: 13), oleks soome-ugri rahvaste ikonograafiline traditsioon erakordselt vana.

Nii tõesti ongi. Olen uurinud motiivi, kus inimese peast saab alguse kolm joont, väljaulatuvat osa või pead, nagu joonistel 3032. Motiiv esineb Lõuna-Uuralis Jamazõ-Taši koopamaalingutel, hiljem Kesk-Uuralis, Fennoskandia ja Siberi kaljujoonistel, Samus IV keraamikal, Minussinski puunikerdustel, Mohenjo Daro pitsatil, Permi pronksvalandeil, Lapi šamaanitrummidel ja Burjaadi ongonitel. Minu arvates sümboliseerib motiiv väärikust, võimekust ja jõudu (Autio 1995: 17; 2000: 180).

Teine motiiv, mis pärineb Kapova ja Jamazõ-Taši koopamaalingutelt, puudutab arve 4, 7, 10, 14 ja 21 . Need esinevad joonte, täppide, motiiviosade ja kaunistustena. Nimetatud arvude tähenduse kohta võib kõige usutavamat informatsiooni saada Boris Frolovi raamatust Tšisla $v$ grafike paleolita (1974). Frolov seostab arve 7, 14 ja 21 kuufaaside ja naise menstruaaltsükliga ning arvu 10 rasedusega, mis loodusliku kuukalendri järgi kestab 10 kuud. 
Et arvude 4, 7 ja 10 esinemine Permi pronksvalandeil on tähelepanuäratavalt ilmne, olen uurinud neid eesmärgiga teha kindlaks, kas nad seostuvad naise, mehe või sisalikuga. Lähteainestikuna olen kasutanud Spitsõni albumit (1906), Oborini ja Tšagini teost (1988) ning Ermitaaži fotokogu. Olen vaadelnud vaid neid pilte, millel on võimalik loendada kaunistusi, motiiviosi vms ehk kokku 160 pilti. Sulde-olendi olen klassifitseerinud meheks, kui tal on habe või jalgade vahel väljaulatuv osa.

Uurimise tulemusena võin tõdeda, et arvud 4, 7 ja 10 esinevad peaaegu ainult seoses naissoost olendiga (näiteks joonised 44-50). Jälgisin ka arvu 5, kuid sel ei olnud selget sidet meessooga, kuigi obi-ugri uskumustes viitab 5 mehele ja 4 naisele. Võimalik, et viie esinemine seoses naisolenditega osutab meesfaktori puudumisele.
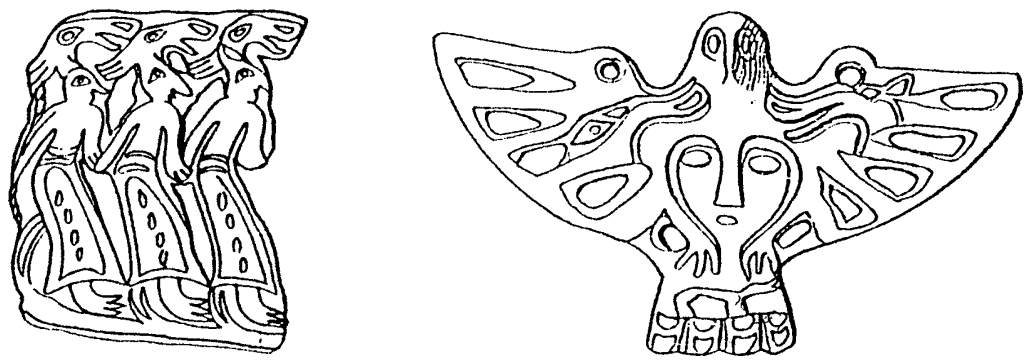

Joonised 44.-45. Arv neli: 44 - sulde-naisi (Garamihha, Spitsõn 154); 45 - lind näoga rinnal. Kišert. (Spitsõn: 1906: 268).
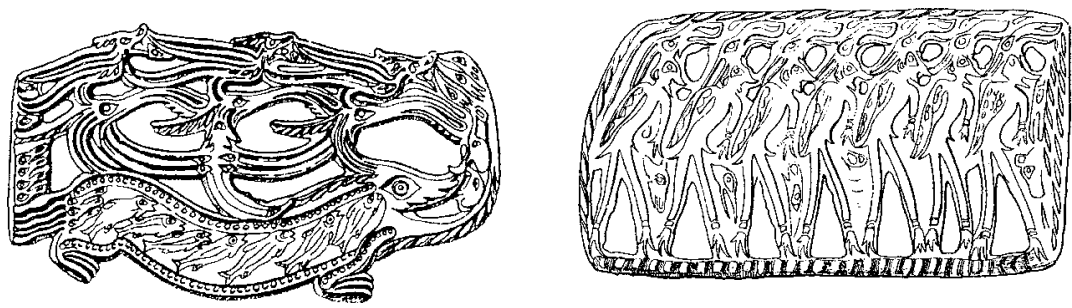

Joonised 46.-47. Arv seitse: 46 - sisalik, kelle kõhus on seitse kala (Nõrgõnda, Spitsõn 108); 47 - seitse suldet. Peškova. (Spitsõn 1906: 152). 

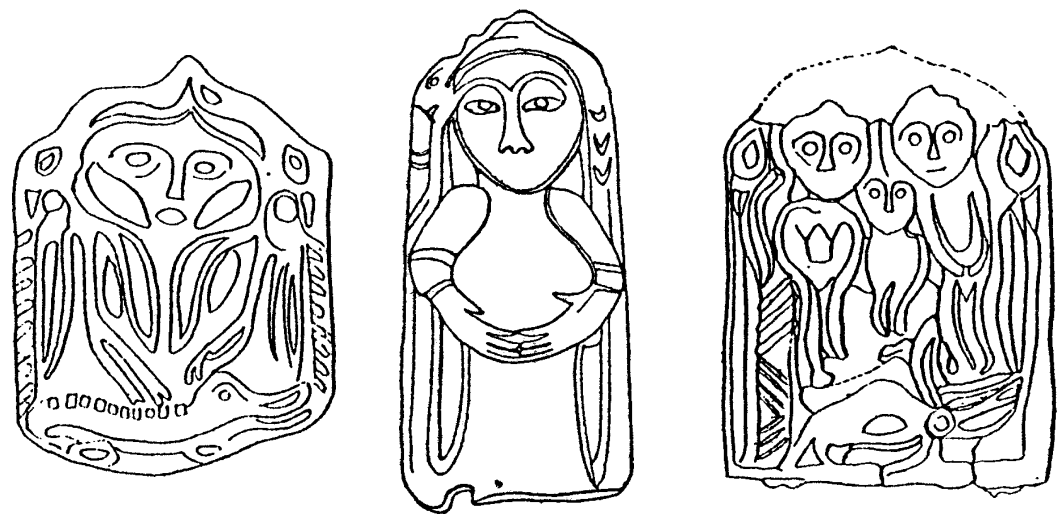

Joonised 48.-50. Arv kümme: 48 - sisaliku seitse seljakaunistust ja ühendus naisega. Grudjata. (Spitsõn 1906: 193); 49 - õnnistatud olekus naine. Kümme sõrme osutavad raseduse kestusele ja kolm kaunistust pea paremal poolel veel oodata olevale ajale. Vologda kubermang (?). (Spitsõn 1906: 209); 50 - kümme kuud on möödas, millele viitab emapoolsete äärekaunistuste arv. Redikor. (Spitsõn1906: 186).
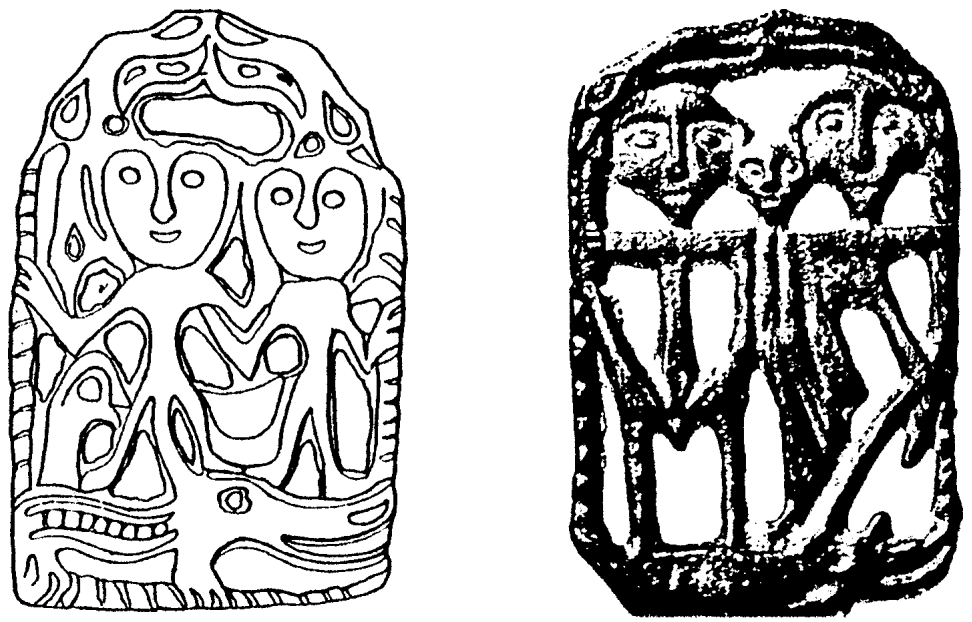

Joonised 51. ja 52. Sisaliku seos viljakusega: 50 - ühendus sisalikuga jalgade vahelt. Kišert. (Spitsõn 1906: 175); 51 - ühendus naisega. Pobobõka. (Oborin \& Tšagin 1988: joonis 116). 
Arvud 4, 7 ja 10 esinevad märkimisväärselt sageli ka sisalikumotiivi osades ja kaunistustes (näiteks joonistel 46 ja 48). Sisalikumotiivi puhul olen täheldanud selget seost viljakusega (näiteks joonised 48, 51 ja 52). See sobib seletustega, mille kohaselt sisalik sümboliseeris maad ja maa-alust ehk surnute ilma. Udmurtide uskumustes oli elu kadunukeste kingitus ning hinge andsid elavaile esiisad (Holmberg 1914: 51-53). Kui komi külvas vilja põllule, läks jahile või kalale, palus ta alati õnnistust kadunukestelt (Nalimov 1907: 10). Maa, maa-aluste jõudude ja viljakuse seisukohalt ongi aeg see, mis teeb kasvamise võimalikuks. Vaatlusalused arvud osutavad ka sisalikuga seoses ajale ja viljakusele. Sellest lähtuvalt on sisalik olnud näiteks "perepiltidel" (53-55) niisama tähtis kui turvalisust sisendavad põdrapead.
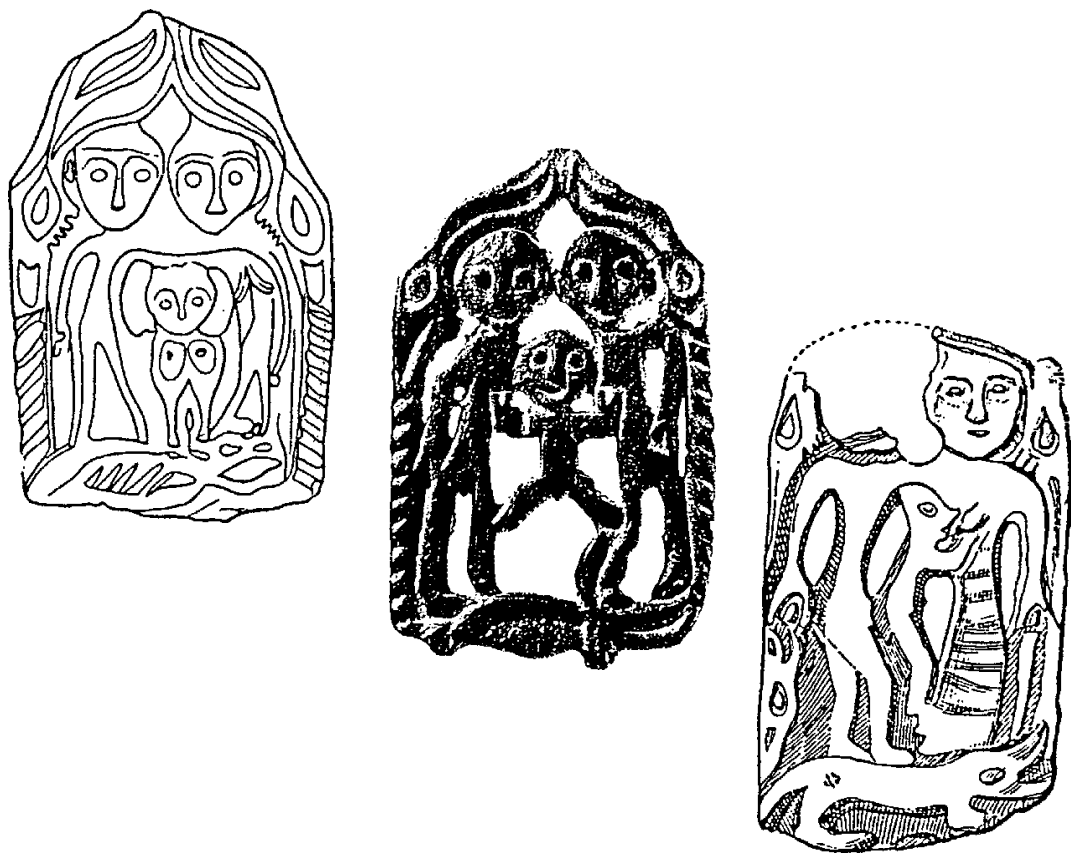

Joonised 53.-55. Lapse sünniga seonduvaid motiive: 53 - Sündis tüdruk! (Spitsõn 1906: 182); 54 - ...ja meil poeg! (Oborin \& Tšagin 1988: joonis 126); 55 - Perekonnaõnn (Spitsõn 1906: 183). 


\section{Naiste eluga seonduv motiiv}

Joonisel 56 on nõtke põderhobune ja selle seljas ratsanik. N. Tšesnokova (1995) on ratsanikku pidanud komi Pera-vägilaseks. Siiski on ratsanik naine nagu teistelgi naisratsutaja motiiviga valanditel. Lugedes kokku motiiviosad, võime täheldada järgmisi arve. Naisratsaniku taga on viis põdrapead, mis osutavad minu arvates vasakul nurgas oleva looma (karu) soole. Naisratsaniku ees on kaks põdrapead, kokku on põderhobuse seljas niisiis $5+2$ ehk seitse pead. Ratsu jalgade alla on sisaliku asemele paigutatud seitse loomapead (suunaga paremale). Kui lugeda kokku need ja ratsu seljas olevad pead, saame arvu 14. All vasemal on kolm loomapead (suunaga üles). Alaservas on niisiis kokku 10 pead. Ratsu ees on lind. Selle sabas ja tiibades kordub naisele või kuu nädalatele viitav arv neli. Lind ise võiks Tšesnokova tõlgenduse kohaselt viidata pulmadele või teispoolsele ilmale (Tšesnokova 1995: 50) või olla ka lihtsalt teejuht.

Naisratsanikku oleks N. Šutova arvates kõige kindlam pidada kõige oleva emaks, kelle vallata oli inimeste saatus. Arv 14 viitab tõenäoliselt ovulatsioonile, mis toimub keskmiselt menstruaaltsükli 14. päeval. Kui naine ei taha saada last, tuleb tal hoiduda seksuaalvahekordadest 7.-21. päevani (Lauersen \& Whitney 1980: 192).

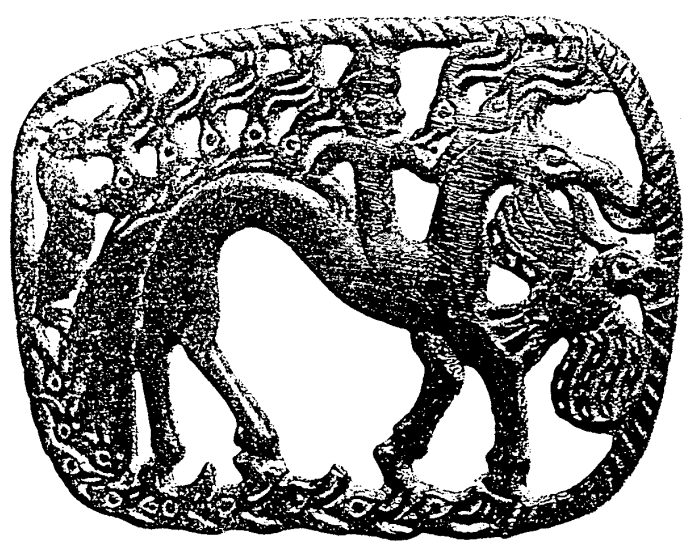

Joonis 56. Põderhobune ja naisratsanik. 5.-6. saj (Oborin), 8. saj (Melnitšug): 19. saj juhuslik leid Permi kubermangust. 7 × 9,3 cm. Permi ülikooli Selikmani kogu. 

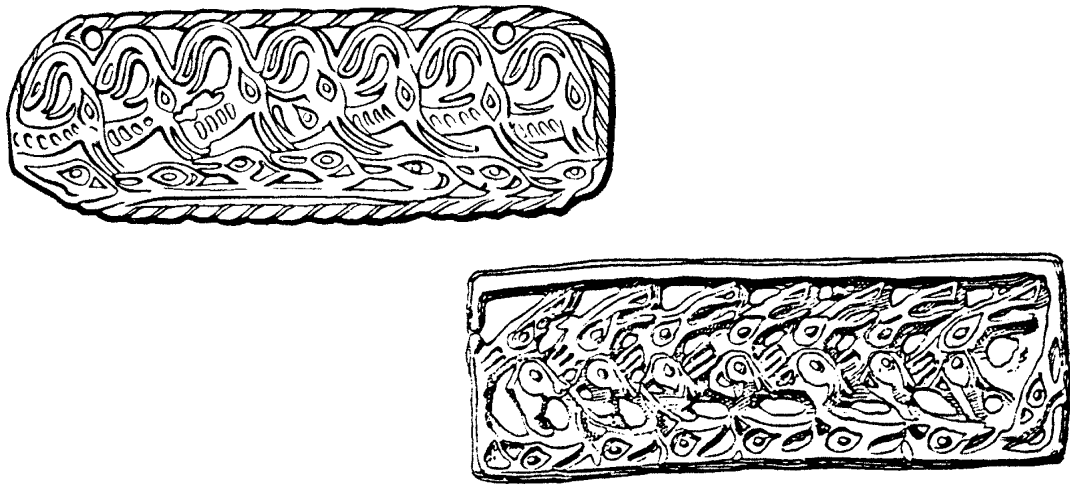

Joonised 57. ja 58. Arvud 7, 14 ja 21. 57 - pronksplaat $7+7=14$. (Spitsõn 1906: 147). $58-7+7+7=21$. (Spitsõn 1906: 148).

Permi valandites korduvad arvud 7, 14 ja 21 (näiteks joonised 57 ja 58), nii et need on naiste teadvuses figureerinud. Arvu 10 on kõige usaldusväärsem seostada raseduse kestusega, sest meeste maailmas ei leidu sellele piisavalt mõistlikke seletusi. Nii seondub kogu valandi motiivistik väga tihedalt naise eluga. Siin on sümboolselt väljendatud soodsaim viljastumise aeg ja raseduse kestus. Minu tõlgenduse toetuseks olgu öeldud, et just naised on valanud pronksesemeid nii ehteina kandmiseks kui ka usundiliseks tarbeks (Golubeva 1984; Rozenfeldt 1987: 151).

\section{"Kalevalaga" võrreldav kultuuripärand}

Permi rahvastel, unustamata seejuures ka obiugrilasi, on täiesti soome "Kalevalaga" võrreldav kultuuripärand. Selle pronksi valatud värsiridade mõistmine on nõudnud ja nõuab edaspidi rohkesti uurimistööd. Viimase saja aasta jooksul on juba paljusid motiive suudetud seletada üsna usutavalt. Selliste hulka kuulub veelind soomeugrilased ongi "veelinnurahvas", kui laenata Eesti ekspresidendi kirjanik Lennart Meri väljendit. Kahe veelinnuga motiiv kujutab Tšõž-pardi poegi Jeni ja Omõli. Kahe loomaga, kellel on koonud vastamisi, kujutatakse kõige tõenäolisemalt abielu, kus abikaasad kuuluvad erinevatesse totemistlikesse gruppidesse. Totemismile viitavad ka medaljonid, kus on kujutatud karu pead, käpad 
koonu kõrval. Selle taga võib olla obi-ugri uskumus: karu oli taevase jumala tütar, kes oli sõnakuulmatuse tõttu maa peale saadetud.

Sulde-motiiv ja sama üldine väljasirutatud tiibade ja rinnale loodud näoga linnumotiiv võivad arvatavasti pärineda juba valandite varaseimate vormide ajast ning kujutada totemistlikke rühmitusi (joonised 21 ja 29). Mõlemal motiivil on selgesti uskumustele viitavaid jooni, nii näiteks mõjuvad juba üksnes põtrade vastamisi asetatud pead turvalisust väljendavana. Eriti märgatav on see lapse sünni puhuks valatud kujutistes. Valandimotiivides võib näha ilmset arengut inimnäoliste jumalolendite ja jumalannade suunas.

Märkimisväärne on, et Permi pronksvalanditel peegelduv kultuur seostub naistega. Muu hulgas ilmneb see asjaolus, et paljud motiivid, nagu näiteks veelind, naisratsanik ja elupuu, esinevad naiste käsitööde kaunistustes Vepsa ja Karjalani välja. Sellest hoolimata on pronksvalandid kuulunud ka meeste kultusesemete hulka, nagu osutab Udmurtias Kuzmino kalmistult hauast nr 133 leitud kaelaskantav ripats (Ivanova 1992: pilt 54).

Tõlkinud Kadri Tamm

\section{Kommentaar}

${ }^{1}$ Tootempõhjapõdra Meandaši lugude põhjalik analüüs on esitatud Enn Ernitsa artiklis "Hõimlane verejõe tagant: saami muinaslood tootempõhjapõdrast”. Mäetagused 4-10.

\section{Kirjandus}

Anutšin, D. N. 1899. K istorii i verovanii u Priuralskoi tšudi. Materialõ po arheologii vostotšnõhh guberni Rossii 3. Moskva.

Appelgren-Kivalo, H. 1912. Die Grundzüge des skytisch-permischen Ornamentstiles. Suomen Muinaismuistoyhdistyksen Aikakauskirja XXVI.

Aspelin, J. R. 1877-1884. Antiquités Nord Finno-Ougrien. Helsinki.

Autio, E. 1981. Karjalan kalliopiirrokset. Helsingi: Otava.

Autio, E. 1995. Horned anthropomorphic Figures in Finnish Rock-paintings. Shamans or something else? Fennoscandia archaeologica XII. Helsinki.

Autio, E. 2000. Kotkat, hirvet, karhut. Permiläistä pronssitaidetta. Jyväskylä: Atena.

Formozov, A. A. 1969. Otšerki po pervobõtnomu iskusstvu. Naskalnõje izobraženija i kamennõje izvajanija epohhi kamnja i bronzõ na territorii SSSR. Moskva. 
Frolov, B. A. 1974. Tšisla v grafike paleolita. Novosibirsk.

Golubeva, L. A. 1966. Konkovõje podveski Verhnego Prikamja. Sovetskaja Arheologija 3.

Golubeva, L. A. 1978. Simvolõ solntsa v ukrašenijahh finno-ugrov. Drevnaja Russ $i$ slavjane. Moskva.

Golubeva, L. A. 1979. Zoomorfnõje ukrašenija finno-ugrov. Moskva.

Golubeva, L. A. 1984. Ženštšinõ-liteištšitsõ. Sovetskaja Arheologija 4.

Gribova, L. S. 1972. Složnõi obraz permskogo zverinogo stilja. Etnografija i folklor komi. Sõktõvkar.

Gribova, L. S. 1975. Permski zverinõi stil. Problemõ semantiki. Moskva.

Gribova, L. S. 1984. Kultovaja plastika Heibida-Pedarõ. Arheolo-etnografitšeskije aspektõ Severnogo Priuralja. Sõktõvkar.

Gurina, N. N 1956. Oleneostrovski mogilnik. Materialõ i issledovanija po arheologii SSSR 47. Moskva \& Leningrad.

Holmberg, U. 1914. Permalaisten uskonto. Porvoo.

Huurre, M. 1983. Pohjois-Pohjanmaan ja Lapin esihistoria. Kuusamo.

Iljina, I. V. 1994. Glava 11 (Iskusstvo). Traditsionnaja kultura naroda Komi. Sõktõvkar.

Komi jözkostsa iskusstvo / Narodnoje iskusstvo Komi. Moskva 1992.

Korepanov, K. I. 1978. K istorii izutšenija zverinogo stilja Prikamja. Problemõ istorii dokapitalitšeskihh formatsii. Moskva.

Korepanov, K. I. 1995. Otraženije predstavleni o dreve žizni v iskusstve permskogo zverinogo stilja. Krajevetšeski sbornik. Naberežnõje Tšelnõ. Tatarstan.

Kossarev, M. F. 1984. Zapadnaja Sibir v drevnosti. Moskva.

Lauersen, N. \& Whitney, S. 1980. Nainen - tunne itsesi. Gynekologia ja sukupuolielämä. (Orig: It's Your Body. A Woman's Guide to Gynecology). Keuruu.

Nalimov, V. P. 1907. Zagrobnõi mir po verovanijam zõrjan. Etnografitšeskoje obozrenije LXXII-LXXIII. Moskva.

Oborin, V. A. \& Tšagin, G. N. 1988. Iskusstvo Prikamja. Tšudskije drevnosti Rifeja. Permski zverinõi stil. Perm.

Obõdennov, M. F. \& Korepanov, K. I. 1997. Iskusstvo Urala i Prikamja. Epohha kamnja i bronzõ. Ufaa.

Rozenfeldt, R. L. 1987. Prikamskije finnõ. Finno-ugrõ i baltõ v epohhu srednevekovja. Arheologija SSSR. Moskva.

Rõbakov, B. A. 1979. Kosmogonitšeskaja simvolika "tšudskihh" šamanskihh bljašek i russkihh võšivok. Finno-ugrõ i slavjane. Dokladõ pervogo Sovetsko-Finljandskogo simposiuma. Leningrad.

Sidorov, A. S. 1972. Ideologija drevnego naselenija Komi kraja. Etnografija i folklor Komi. Sõktõvkar.

Smirnov, A. P. 1952. Otšerki drevnei i srednevekovoi istorii narodov Povolžja i Prikamja. Materialõ i issledovanija po arheologii SSSR 28. 
Spitsõn, A. A. 1899. Šamanizm v otnošenii k russkoi arheologii. Zapiski Russkogo arheologitšeskogo obštšestva XI: I, II.

Spitsõn, A. A. 1906. Šamanskije izobraženija. Zapiski Otdelenija russkoi slavjanskoi arheologii Russkogo arheologitšeskogo obštšestva VIII: 1. Sankt-Peterburg.

Studzitskaja, S. V. 1994. Neolititšeskije ritualnõje “žezlō" lesnoi polosõ Jevrazii. Tezissõ dokladov na meždunarodnoi konferentsii, posvjaštšjonnoi 100letiju so djna roždenija professora V. I. Ravdonikasa. Sankt-Peterburg.

Šmidt, A. V. 1927. K voprossu o proishoždenii Permskogo zverinogo stilja. Sbornik Muzeja Antropologii i Etnografii. Leningrad.

Šutova, N. I. 1998. Ženskoje bož estvo plodorodija v duhhovnoi žizni finno-ugrov Priuralja. Ob etnitšeskoi psihhologii udmurtov. Iževsk.

Zbrujeva, A. V. 1952. Istorija naselenija Prikamja v ananinskuju epohhu. Materialõ i issledovanija po arheologii SSSR 30. Moskva.

Žerebtsov \& Saveljeva \& Smetanin 1996. Istorija respubliki Komi. Sõktõvkar.

Tallgren, A. M. 1931. Luoteis-Siperian kulttuurikosketuksista Kr. s. aikaan. Kalevalaseuran vuosikirja 11. Porvoo.

Tallgren, A. M. 1934. Die Altpermische Pelzwarenperiode an der Petšora. Suomen Muinaistoyhdistyksen Aikakauskirja XL.

Teplouhhov, F. A. 1893. Drevnosti Permskoi Tšudi v vide basnoslovnõhh ljudei i životnõhh. Permski krai 2. Perm.

Tšarnoluski, V. V. 1965. Legenda ob olene-tšeloveke. Moskva.

Tšesnokova N. N. 1988. Klassifikatsii i tipologizatsii v izutšenii arheologitšeskihh istotšnikov (na materiale finno-ugorskogo izobrazitelnogo iskusstva). Sõktõvkar.

Tšesnokova N. N. 1995. The Myth of the Northern Sub-Urals. Folk Belief Today. Tartu.

Tšižova L. V. 1982. K voprossu ob ideologii srednevekovogo naselenija Prikamja. Sovetskaja Arheologija 3.

Tšižova L. V. 1987. Kultovoje litje lesnoi polosõ Jevrazii v sisteme animistitšeskihh predstavlenii ugro-samoditsev. Novõje arheologitšeskije issledovanija na territorii Urala. Iževsk. 